\title{
Enhancement of pico- and nanoplankton growth by coral exudates
}

\author{
C. Ferrier-Pagès ${ }^{1, *}$, N. Leclercq ${ }^{1}$, J. Jaubert $^{1}{ }^{1}$, S. P. Pelegrí ${ }^{2, * *}$ \\ 'Observatoire Océanologique Européen, Centre Scientifique de Monaco, Av. Saint-Martin, 98000 Monaco (Principality of Monaco) \\ ${ }^{2}$ Observatoire Océanologique, Marine Microbial Ecology Group, ESA 7076 CNRS, BP 28, 06234 Villefranche-sur-Mer cedex, France
}

\begin{abstract}
The enhancement of pico- and nanoplankton cell biomass by coral exudates was studied in the laboratory. Two types of mesocosms were used, the first one containing only a carbonate sand layer (control mesocosm) and the second one containing a coral layer over the carbonate sand layer (coral mesocosm). During $10 \mathrm{~h}$ incubations, we followed the concentration of bacteria, cyanobacteria, and of auto- and heterotrophic flagellates, as well as the concentrations of inorganic ( $\mathrm{N}$ and $\mathrm{P}$ ) and organic (dissolved organic carbon, DOC) nutrients. There were no significant differences in inorganic nutrient concentrations between mesocosms. However, DOC concentrations in coral mesocosms exhibited peaks 5- to 13fold higher than control mesocosm levels; these peaks took place between 13:00 and 17:00 h and lasted for ca $2 \mathrm{~h}$. As a consequence, microbial growth was significantly enhanced in coral mesocosms. At the end of the incubations, bacterial biomass was 6 -fold higher in coral relative to control mesocosms. Autotrophic biomass was 3 to 5 times higher in coral mesocosms. These results indicate that small amounts of coral exudates ( 0.5 to $10 \%$ of maximum DOC concentrations) are enough to greatly stimulate microbial growth.
\end{abstract}

KEY WORDS: Picoplankton - Nanoplankton · Corals Organic carbon (DOC) - Mesocosm

Coral reefs are areas of high productivity (Lewis 1977) due to a rapid turnover of organic and inorganic nutrients (Crossland \& Barnes 1983). Heterotrophic bacteria have been recognized as one of the most important agents of carbon and nitrogen cycling in coral reefs (Ducklow 1990, Sorokin 1994, Charpy-Roubaud et al. 1996), and bacterial productivity in reef waters is extremely high compared to the open ocean (Moriarty et al. 1985, Linley \& Koop 1986, Ducklow 1990). Small

\footnotetext{
•E-mail: ferrier@unice.fr

- Present address: Laboratoire d'Océanographie et de Biogéochimie, UMR 6535 CNRS, Campus de Luminy, Case 901, 163 Avenue de Luminy, 13288 Marseille cedex 9, France
}

autotrophs $(<20 \mu \mathrm{m})$, often representing a large fraction of the total phytoplanktonic biomass, also show high production rates in reef waters (Furnas et al. 1990, Charpy et al. 1992, Ferrier-Pagès \& Gattuso 1998).

It has therefore been suggested that large amounts of dissolved and particulate organic matter (DOM/ POM) are needed to sustain these high production rates (Moriarty 1979). A number of potential sources such as phytoplanktonic exudates, benthic fluxes, and particle degradation - are at the origin of this organic matter (D'Elia \& Wiebe 1990). Corals have been suggested to be an important source of POM and DOM in reef waters (Crossland 1987). Indeed, marked changes in bacterial and POM concentrations have been observed over reef flats (Moriarty 1979), and the highest pico- and nanoplankton production rates have often been measured above corals (Ducklow 1990, Sorokin 1993, 1994). Studies performed at Lizard Island have measured 10-fold increases in bacterial production rates in waters flowing off the back reef compared to those of the reef front (Moriarty et al. 1985).

The contribution of coral mucus (POM) to bacterial production has been assessed in a number of studies (Ducklow \& Mitchell 1979, Herndl \& Velimirov 1986. Paul et al. 1986, Schiller \& Herndl 1989, Coffroth 1990). However, coral mucus can only be used by microbes if it is retained in the reef long enough for decomposition to occur (Capone et al. 1992). Moreover, an important fraction of this mucus may be refractory and thus not consumed during its short transit time across the reef (Hatcher \& Sanmarco 1983). Only a few studies have reported DOM fluxes from corals (Means \& Sigleo 1986, Crossland 1987, Ferrier-Pagès et al. 1998). Labile DOM like amino acids and sugars are assimilated rapidly by free-living bacteria (Williams 1981) as well as by autotrophic plankton (Palenik \& Morel 1990). However, whether DOM fluxes from corals into the overly- 
ing water could sustain large microbial production rates remains to be experimentally tested (Ducklow 1990).

The purpose of this work was to study the capacity of dissolved coral exudates to enhance microbial production. Our main objectives were: (1) to determine the extent of coupling between coral exudation and picoand nanoplanktonic growth, and (2) to compare biomass production of both auto- and heterotrophic microbes. For this purpose, 2 mesocosms were set up, one containing only a carbonate sand layer and the other one containing a coral layer over the carbonate sand layer. Auto- and heterotrophic populations of pico- and nanoplankton were incubated in dialysis bags, directly over the sediment or the corals, and biomass production rates after $10 \mathrm{~h}$ incubations were compared.

Máteriai and methodis. Two dîfîerent sets oí experiments were performed. In the first set of experiments (Expt A), a mesocosm was set up successively with and without a coral cover over the sediment (coral and control mesocosm, respectively). In the second set of experiments (Expt B), 2 mesocosms (coral and control mesocosms) were used simultaneously. These 2 approaches were used to eliminate any mesocosm effect.

Experimental setup: The mesocosms were assembled in aquaria $(60 \times 60 \times 60$ and $40 \times 30 \times 30 \mathrm{~cm}$, Expts $A$ and B respectively) following Leclercq et al. (1999) (Fig. 1). A $5 \mathrm{~cm}$ carbonate sand layer separated the main seawater reservoir from a small volume of confined seawater. The aquaria were filled with Mediterranean seawater passed through a sand filter and heated to $26^{\circ} \mathrm{C}$ (controller EliWell PC 902T and Biotherm 2000 Rena, Expts A and B respectively). This temperature was comparable to the temperature of

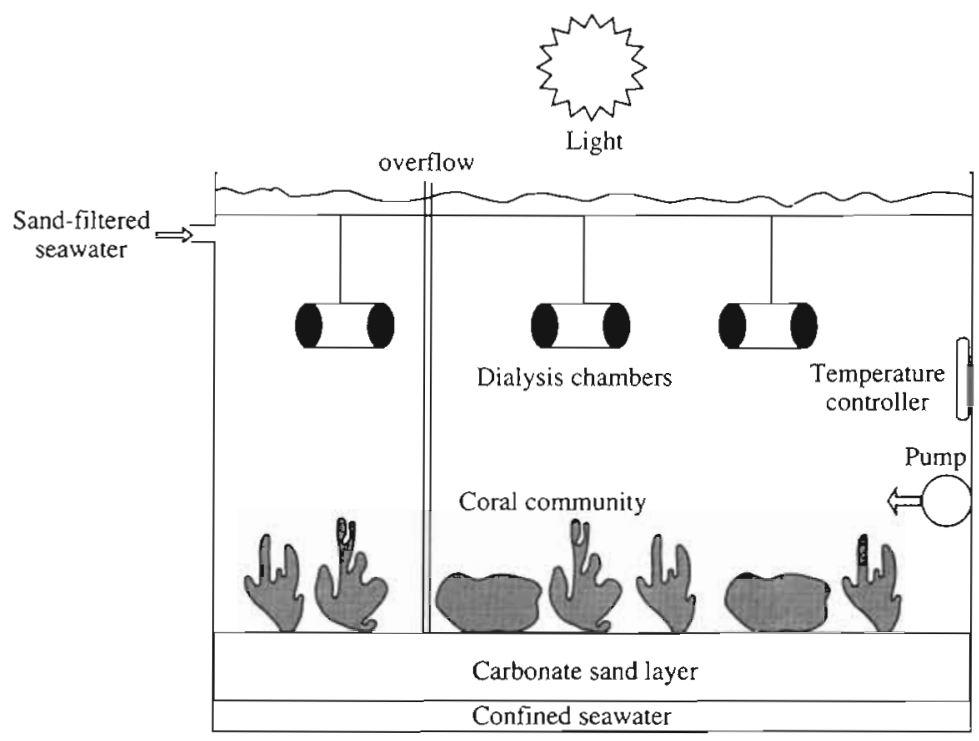

Fig. 1: Design of the experimental setup. Drawing of a mesocosm containing a coral cover
Mediterranean seawater at the time of the experiment (25 to $26^{\circ} \mathrm{C}$, July to September). The water in the mesocosms was continuously aerated (air pump Alizé, Rena) and stirred (powerhead Maxijet 1000 and C20 Rena, experiments $\mathrm{A}$ and $\mathrm{B}$ respectively). The continuous seawater renewal $\left(5 \% \mathrm{~h}^{-1}\right)$ was stopped during the experiments. Light was provided by a $400 \mathrm{~W}$ metal halide lamp (300 $\mu \mathrm{mol}$ photons $\mathrm{m}^{-2} \mathrm{~s}^{-1}$, Philips HPI-T) with a 12:12 h photoperiod. The reef community was composed of different scleractinian coral colonies collected in the Red Sea and introduced in the mesocosms 3 yr before the present study. The species composition was: Expt A, Stylophora sp., Acropora sp., Favia sp. Galaxea sp., and Euphyllia ancora; Expt B, Pectinia paeonia, Montipora sp., Favia sp. and Euphyllia ancora.

Expí A: A microplankionic community was obtained from the Mediterranean Sea in the morning at $2 \mathrm{~m}$ depth and brought back to the laboratory. This community was immediately size-fractionated by gravity and reverse flow filtration, to avoid cell breakage (Furnas \& Mitchell 1986), through nylon screens and Nuclepore $^{\text {TM }}$ filters. Three size-classes were obtained in order to remove different predators: $<2 \mu \mathrm{m}$ (bacteria, cyanobacteria and picoflagellates), $<5 \mu \mathrm{m}$ (previous cells and nanoflagellates) and $<10 \mu \mathrm{m}$ (previous cells and small ciliates). Aliquots of each fraction were then carefully transferred into 3 perspex chambers $(100 \mathrm{ml})$ and closed at each end by a dialysis membrane (Furnas et al. 1990, Ferrier-Pagès and Gattuso 1998) of 14000 to $20000 \mathrm{Da}$ cut off (Spectra/Por). These membranes allowed the exchange of DOM but prevented grazing of microbes by the corals. Diffusive exchange of a mixture of ${ }^{14} \mathrm{C}$-labelled amino acids between chamber and mesocosm water took $<30 \mathrm{~min}$ to $1 \mathrm{~h}$ (unpubl. results). The chambers were incubated for $10 \mathrm{~h}$ in the coral mesocosm. The corals were then removed from the mesocosm, the water completely renewed and other chambers incubated the following day for $10 \mathrm{~h}$ in the control mesocosm. Samples were taken at the beginning and the end of the incubations to measure pico- and nanoplanktonic, inorganic nutrient, and dissolved organic carbon (DOC) concentrations. These experiments were repeated twice at a 1 wk interval and will be referred as Expts A1 and A2.

Expt B: Seawater was collected at $2 \mathrm{~m}$ depth and filtered under reverse flow onto $0.8 \mu \mathrm{m}$ Millipore $^{\mathrm{TM}}$ filters in order to recover the bacterial fraction. Bacteria were transferred into 3 replicate perspex chambers $(50 \mathrm{ml})$ closed by 2 dialysis membranes of 20000 Da cut off. The chambers were then incubated simultaneously in the coral and control mesocosms for $10 \mathrm{~h}$. Samples were taken at the beginning and the end of the 
incubations to measure bacterial, inorganic nutrient, and DOC concentrations. This experiment was repeated 3 times at $1 \mathrm{~d}$ intervals and will be referred to as Expts B1, B2 and B3.

Analysis and calculations: Inorganic nutrients and DOC: Inorganic nitrogen (nitrate, nitrite and ammonium) and phosphate were measured on an Alliance II autoanalyser (Strickland \& Parsons 1972), and DOC by high temperature catalytic oxidation (HTCO) (DOC was not measured in Expt A2). Samples for DOC analysis were filtered through acid-washed $(10 \% \mathrm{HCl})$ $0.2 \mu \mathrm{m}$ polyethersulphone membrane filters (Gelman). Once placed onto the filtering unit $\left(500^{\circ} \mathrm{C}\right.$ ignited glasswater), the filters were washed again with $20 \mathrm{ml}$ Milli-Q water prior to sample collection into $20 \mathrm{ml}$ ignited Pyrex tubes. Samples were then acidified to $\mathrm{pH} \leq 2$ with $2 \mathrm{~N} \mathrm{HCl}$ and stored at $5^{\circ} \mathrm{C}$ pending analysis. Samples were sparged with an artificial gas mixture (containing $\leq 0.1 \mathrm{CO}, \mathrm{CO}_{2}$ or hydrocarbons) in order to eliminate inorganic carbon and measured on a Shimadzu TOC 5000. DOC concentrations were calculated with a standard calibration curve made with potassium biphthalate. The coefficient of variation of duplicate injections was always $<2 \%$.

Pico- and nanoplanktonic concentrations: Cells in each perspex chamber were enumerated in triplicate. Ten $\mathrm{ml}$ samples were fixed with borax-buffered formaldehyde ( $2 \% \mathrm{v} / \mathrm{v}$ final concentration) and stained with DAPI (4'6 diamidino-2-phenylindole, Porter \& Feig 1980). Following that, they were filtered onto $0.22 \mu \mathrm{m}$ black Nuclepore ${ }^{\mathrm{TM}}$ filters and stored at $-20^{\circ} \mathrm{C}$ prior to enumeration. Cells were counted under a magnification of $\times 1000$ with a Leica epifluorescence microscope equipped with an HBO-100 epifluorescence illuminator and the excitation/barrier filter sets for UV, blue and green light. Bacteria and heterotrophic flagellates appear blue under UV excitation (Caron 1983). Autotrophic flagellates were distinguished by the autofluorescence of the chlorophyll a (visualized as red) and chroococcoid cyanobacteria of the phycoerythrin (visualized as yellow, Waterbury et al. 1986). Cell abundances were converted into carbon biomass $(B$, $\mu \mathrm{C} \mathrm{Cl}^{-1}$ ) according to the following equation:

$$
B=N \times V \times C
$$

where $N$ is the cell abundance (cell $\mathrm{ml}^{-1}$ ), $V$ the geometrical cell volume $\left(\mu^{3}\right)$, and $C$ the conversion factor (125 fg C $\mathrm{mm}^{-3}$ for heterotrophic bacteria [Pelegrí et al. 1999], $183 \mathrm{fg} \mathrm{C} \mathrm{m}^{-3}$ for pico- and nanoflagellates, and $200 \mathrm{fg} \mathrm{C} \mathrm{mm}^{-3}$ for cyanobacteria [Caron et al. 1995]). Cell volumes were $0.06,1.77$ and $65 \mu^{3}$ for heterotrophic bacteria, pico- and nanoflagellates respectively.

Statistical analysis of the differences between coral and control mesocosms was performed on StatView by using 1-factor ANOVAs. When a significant effect was
Table 1. Nutrient concentrations $(\mu \mathrm{M})$ and increases in biomass ( $\mu \mathrm{g} \mathrm{Cl}^{-1}$ ) in control and coral mesocosms during the various incubations (mean \pm standard error of the mean). Expt A: the means of $<2,<5$ and $<10 \mu \mathrm{m}$ size fractions are given for bacteria, cyanobacteria and autotrophic pico- and nanoflagellates (APF, ANF); ANOVAs were performed to test the differences between mesocosms. $p<0.5$ is significant. Nutrient concentrations in Expt $\mathrm{B}$ are in the same range as for Expt $\mathrm{A}$

\begin{tabular}{|c|c|c|c|}
\hline Group & $\begin{array}{c}\text { Control } \\
\text { mesocosm }\end{array}$ & $\begin{array}{c}\text { Coral } \\
\text { mesocosm }\end{array}$ & $\begin{array}{l}\text { ANOVA } \\
\text { probability }\end{array}$ \\
\hline \multicolumn{4}{|l|}{ Expt A1 } \\
\hline \multicolumn{4}{|l|}{ Nutrients $(\mu \mathrm{M})$} \\
\hline Nitrite & $0.02 \pm 0.01$ & $0.02 \pm 0.01$ & $p=0.20$ \\
\hline Nitrate & $0.20 \pm 0.01$ & $0.25 \pm 0.01$ & $\mathrm{p}=0.74$ \\
\hline Ammonium & $0.01 \pm 0.01$ & $0.02 \pm 0.01$ & $\mathrm{p}=0.10$ \\
\hline Phosphate & $0.03 \pm 0.01$ & $0.03 \pm 0.01$ & $p=0.76$ \\
\hline \multicolumn{4}{|l|}{ Groups $\left(\mu \mathrm{g} \mathrm{C}^{-1}\right)$} \\
\hline Bacteria & $0.50 \pm 0.07$ & $3.27 \pm 0.33$ & $p<0.001$ \\
\hline Cyanobacteria & $0.25 \pm 0.07$ & $0.78 \pm 0.05$ & $p<0.001$ \\
\hline APF & $0.05 \pm 0.01$ & $0.17 \pm 0.01$ & $p<0.001$ \\
\hline ANF & $2.04 \pm 1.06$ & $5.90 \pm 1.44$ & $\mathrm{p}=0.040$ \\
\hline \multicolumn{4}{|l|}{ Expt A2 } \\
\hline \multicolumn{4}{|l|}{ Nutrients $(\mu \mathrm{M})$} \\
\hline Nitrite & $0.03 \pm 0.01$ & $0.02 \pm 0.01$ & $p=0.20$ \\
\hline Nitrate & $0.24 \pm 0.02$ & $0.21 \pm 0.04$ & $p=0.74$ \\
\hline Ammonium & $0.02 \pm 0.01$ & $0.03 \pm 0.01$ & $p=0.10$ \\
\hline Phosphate & $0.03 \pm 0.01$ & $0.04 \pm 0.01$ & $p=0.76$ \\
\hline \multicolumn{4}{|l|}{ Groups ( $\left.\mu \mathrm{g} \mathrm{C}^{-1}\right)$} \\
\hline Bacteria & $2.44 \pm 0.46$ & $14.39 \pm 1.15$ & $p<0.001$ \\
\hline Cyanobacteria & $0.24 \pm 0.05$ & $2.50 \pm 0.25$ & $p=0.004$ \\
\hline APF & $0.01 \pm 0.01$ & $0.05 \pm 0.01$ & $p=0.010$ \\
\hline ANF & $0.50 \pm 0.13$ & $2.40 \pm 0.39$ & $p=0.19$ \\
\hline \multicolumn{4}{|l|}{ Expt B1 } \\
\hline Bacteria ( $\mu \mathrm{g} \mathrm{C}^{-1}$ ) & $2.90 \pm 1.1$ & $14.30 \pm 0.55$ & $p<0.001$ \\
\hline \multicolumn{4}{|l|}{ Expt B2 } \\
\hline Bacteria ( $\mu g \mathrm{C}^{-1}$ ) & $4.20 \pm 0.40$ & $9.15 \pm 0.60$ & $p=0.002$ \\
\hline \multicolumn{4}{|l|}{ Expt B3 } \\
\hline Bacteria ( $\mu \mathrm{g} \mathrm{C}^{-1}$ ) & $3.10 \pm 0.90$ & $14.80 \pm 0.40$ & $p<0.0001$ \\
\hline
\end{tabular}

found, the means were compared with a Bonferroni/ Dunn post-hoc test.

Results. Inorganic nutrients and DOC: No significant differences were observed between initial and final nutrient concentrations (ANOVA, $p>0.1$ ) or between coral and control mesocosms (Table 1; ANOVA, $p \geq 0.1$ ). DOC concentrations remained low in control mesocosms (120 to $163 \mu \mathrm{M}$, Table 2), with some occasional small peaks (237 to $385 \mu \mathrm{M})$. In coral mesocosms, important DOC peaks (ca 1300 to $1900 \mu \mathrm{M}$ increase) were observed between 13:00 and 17:00 h and lasted ca $2 \mathrm{~h}$. DOC concentrations during these peaks were significantly higher in coral than in control mesocosms (Table 2 ; unpaired $t$-test, $\mathrm{p} \leq 0.008$ )

Pico- and nanoplanktonic concentrations: Initial concentrations of pico- and nanoplanktonic cells were 
Table 2. Dissolved organic carbon (DOC) concentrations ( $\mu \mathrm{M}$, mean \pm standard error of the mean) measured during the mesocosm experiments. Unpaired $t$-tests were performed to test the differences in DOC between mesocosms, $p<0.05$ is significant

\begin{tabular}{|c|c|c|c|}
\hline Time (h) & $\begin{array}{l}\text { Control } \\
\text { mesocosm }\end{array}$ & $\begin{array}{c}\text { Coral } \\
\text { mesocosm }\end{array}$ & $\mathrm{p}$ \\
\hline \multicolumn{4}{|c|}{ First mesocosm experiment } \\
\hline \multicolumn{4}{|c|}{ Expt A1 } \\
\hline $10: 00$ & $131 \pm 10$ & $157 \pm 17$ & 0.27 \\
\hline $11: 00$ & $128 \pm 20$ & $132 \pm 12$ & 0.67 \\
\hline $12: 00$ & $149 \pm 11$ & $125 \pm 11$ & 0.19 \\
\hline $14: 00$ & $139 \pm 44$ & $117 \pm 12$ & 0.49 \\
\hline $15: 30$ & $123 \pm 13$ & $130 \pm 17$ & 0.72 \\
\hline $17: 00$ & $149 \pm 16$ & $2092 \pm 41$ & 0.001 \\
\hline 10:00 (next daỵ! & $133 \pm 12$ & $160 \pm 10$ & 0.12 \\
\hline \multicolumn{4}{|c|}{ Second mesocosm experiment } \\
\hline \multicolumn{4}{|c|}{ Expt B1 } \\
\hline $11: 00$ & $145 \pm 19$ & $161 \pm 16$ & 0.07 \\
\hline 13:00 & $133 \pm 21$ & $1546 \pm 298$ & 0.002 \\
\hline $14: 00$ & $232 \pm 17$ & $265 \pm 35$ & 0.24 \\
\hline $15: 30$ & $146 \pm 22$ & $145 \pm 12$ & 0.96 \\
\hline $17: 00$ & $137 \pm 17$ & $153 \pm 27$ & 0.08 \\
\hline $18: 00$ & $133 \pm 12$ & $161 \pm 12$ & 0.09 \\
\hline \multicolumn{4}{|l|}{ Expt B2 } \\
\hline $11: 00$ & $130 \pm 27$ & $154 \pm 18$ & 0.25 \\
\hline $13: 00$ & $132 \pm 15$ & $129 \pm 11$ & 0.89 \\
\hline $14: 00$ & $141 \pm 24$ & $174 \pm 12$ & 0.07 \\
\hline $15: 30$ & $147 \pm 24$ & $1473 \pm 17$ & 0.003 \\
\hline $17: 00$ & $237 \pm 19$ & $158 \pm 18$ & 0.04 \\
\hline $18: 00$ & $163 \pm 12$ & $159 \pm 18$ & 0.75 \\
\hline \multicolumn{4}{|l|}{ Expt B3 } \\
\hline $11: 00$ & $208 \pm 12$ & $207 \pm 38$ & 0.92 \\
\hline $13: 00$ & $158 \pm 36$ & $217 \pm 25$ & 0.20 \\
\hline $14: 00$ & $149 \pm 33$ & $170 \pm 39$ & 0.63 \\
\hline $15: 30$ & $385 \pm 37$ & $1937 \pm 172$ & 0.008 \\
\hline $17: 00$ & $140 \pm 25$ & - & - \\
\hline 18:00 & $133 \pm 12$ & $318 \pm 46$ & 0.03 \\
\hline
\end{tabular}

comparable in both Expts A and B: $6 \pm 1 \times 10^{8}$ cells $1^{-1}$ for bacteria, $1.5 \pm 0.5 \times 10^{7}$ cells $\mathrm{l}^{-1}$ for cyanobacteria, $10 \pm 2 \times 10^{5}$ cells $^{1^{-1}}$ for autotrophic picoflagellates, and $7 \pm 1 \times 10^{5}$ cells $^{1^{-1}}$ for autotrophic nanoflagellates. The concentration of heterotrophic flagellates $\left(5.5 \pm 0.2 \times 10^{5}\right.$ and $4.5 \pm 0.1 \times 10^{5}$ cells $l^{-1}$, in Expts A1 and A2 respectively) did not change during the incubations (ANOVA, $\mathrm{p}<0.001$ ) (data not shown). Figs. 2, 3 \& 4 show the increases in microbial biomass (number of cells $\mathrm{l}^{-1}$ and $\mu \mathrm{g} \mathrm{C}^{-1}$ ) for Expts $\mathrm{A} 1, \mathrm{~A} 2$ and $\mathrm{B} 1$ to B3. Biomass increases were different for the various size fractions, the number of predators (and thus grazing) increased with increasing size fractionation. The highest increases in biomass were therefore generally obtained in the smaller fractions, except for autotrophic nanoflagellates, which were mainly present in the $<5 \mu \mathrm{m}$ size fraction, and except when predators were themselves grazed by the higher level. Pico- and nanoplankton growth was always greater in coral than in control mesocosms (ANOVA, $p<0.5$; Table 2). The increase in bacterial biomass was at least 6 -fold higher, while the increase in autotrophic cell biomass (cyanobacteria and autotrophic flagellates) was 3 - to 5-fold higher in coral relative to control mesocosms.

Discussion. No differences in inorganic nutrient concentrations could be observed between control and coral mesocosms; their concentrations remained low and comparable to those observed in situ for reef waters (Smith et al. 1981). However, DOC concentrations varied greatly during these incubations. The small DOC increases (ca $100 \mu \mathrm{M}$ ) observed in control mesocosms could be due to the activity of bacteria and algae in the carbonate sand layer (Sorokin 1993). A much hugher production (ca 1200 to $1600 \mu \mathrm{M}, 5-$ to 13-fold higher than control levels) was measured in coral mesocosms between 13:00 and 17:00 h, and was attributed to corals. Similarly, Means \& Sigleo (1986) measured a huge production of DOC during a $5 \mathrm{~h}$ incubation of the coral Acropora palmata in filtered seawater, and Crossland (1987) observed an in situ production of DOC in coral reefs between noon and 16:00 h. According to the values of primary production previously measured in our coral mesocosms (Leclercq et al. 1999), the DOC released by the corals represented between 12 and $16 \%$ of the photosynthetically fixed carbon. This is in agreement with the few other previous estimates ( 8 to $25 \%$, Crossland 1987, Sorokin 1993).

DOC concentrations in the coral mesocosms decreased ca $2 \mathrm{~h}$ after the peak, as has been already observed for Galaxea fascicularis (Ferrier-Pagès et al. 1998). In that study, colonies of $G$. fascicularis were incubated in $2 \mathrm{l}$ filtered seawater and the release of DOC monitored each 15 min during 10 h using HTCO and ${ }^{14} \mathrm{C}$-radiolabelling techniques. Two important releases of DOC took place, one in the morning and another in the afternoon, followed by a 're-uptake' $2 \mathrm{~h}$ later. The decrease observed could not be attributed to free-living bacteria, which were present in very low concentrations in the filtered incubation medium. Moreover, when prokaryotic inhibitors were added to the seawater, no 're-uptake' occurred, suggesting that coral-associated bacteria (likely epibiotic bacteria) were responsible for the organic carbon disappearance. High bacterial activity has already been measured in the coral surface mucopolysaccharide layer (Herndl \& Velimirov 1986). In our experiments, even assuming that most DOC was rapidly taken up by coral-associated bacteria, enough DOC was still available for planktonic microbial populations. To obtain the total microbial biomass increase measured after $10 \mathrm{~h}$ in the coral mesocosm, between 5 and $150 \mu \mathrm{mol} \mathrm{Cl} \mathrm{Cl}^{-1}$ was needed, if we assume a gross growth efficiency 

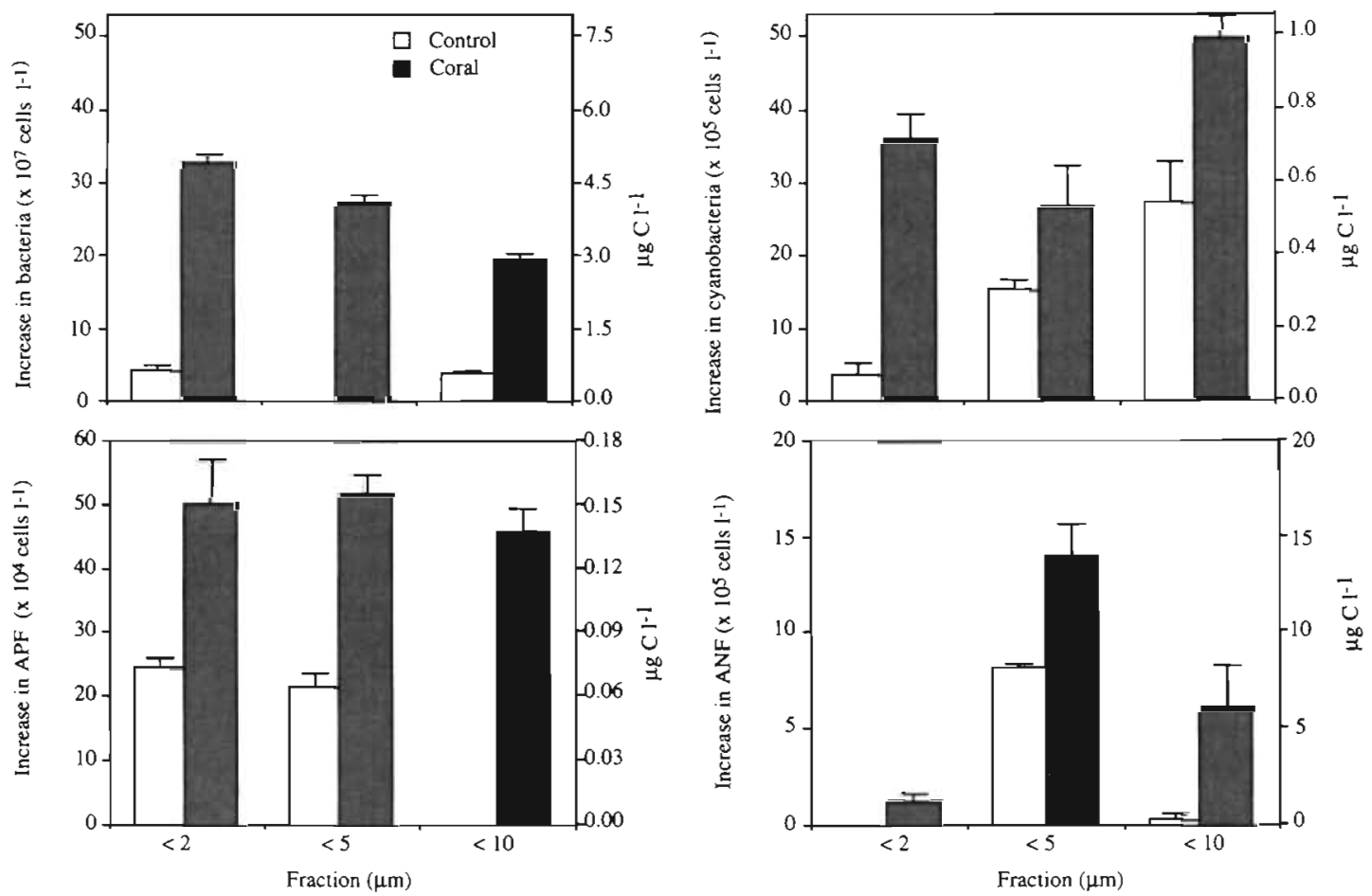

Fig. 2. Expt A.1. Increases in cell number (cell ml-1) and carbon biomass ( $\mu \mathrm{g} \mathrm{Cl}^{-1}$ ) during $10 \mathrm{~h}$ incubations of control (white bars) and coral (grey bars) mesocosms. APF, ANF: autotrophic pico- and nanoflagellates respectively. Pico- and nanoplankton were divided into 3 different size fractions $(<2,<5$ and $<10 \mu \mathrm{m}$ fractions $)$
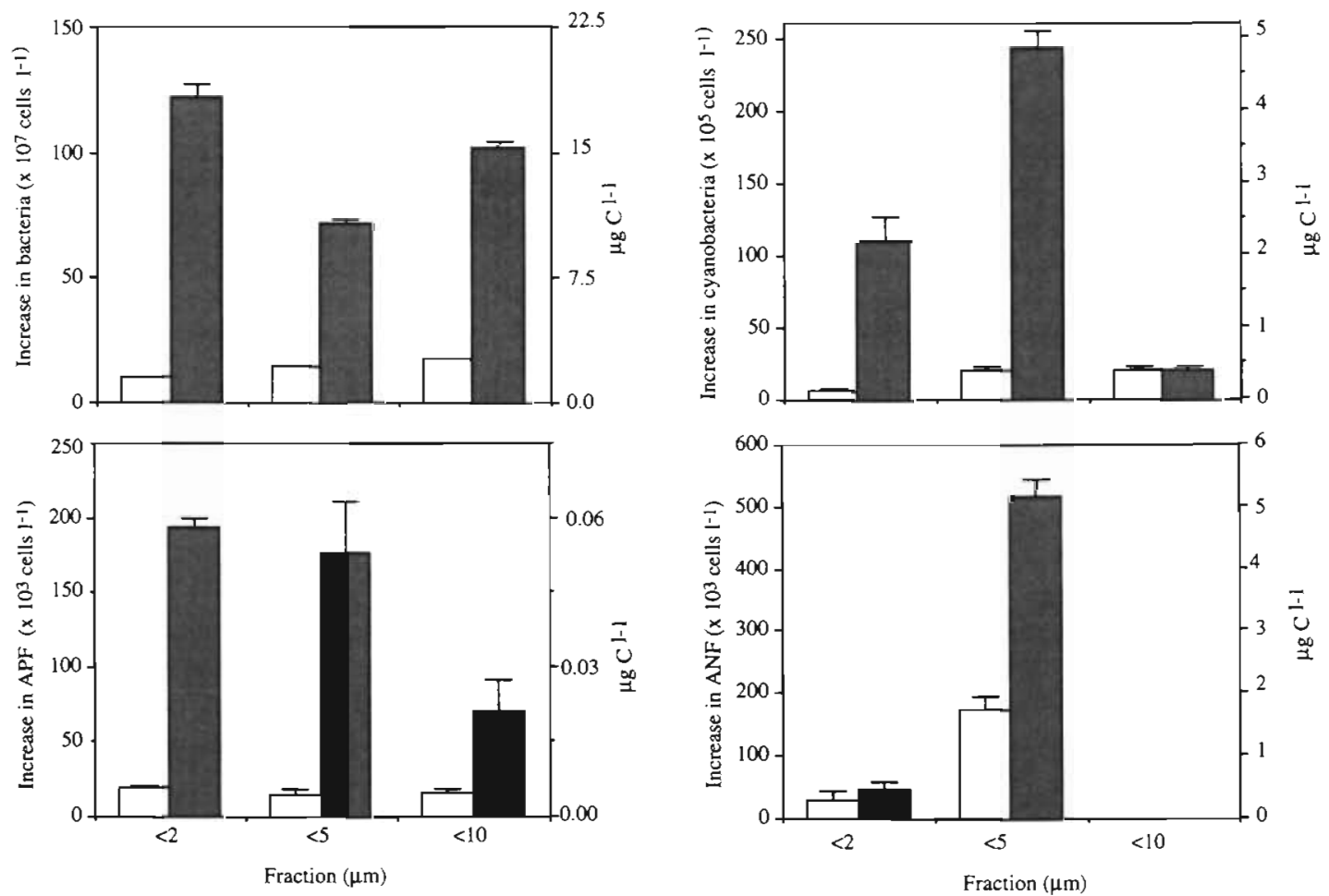

Fig. 3. Expt A2. Increases in cell number (cell $\mathrm{ml}^{-1}$ ) and carbon biomass ( $\mu \mathrm{g} \mathrm{Cl}^{-1}$ ) during $10 \mathrm{~h}$ incubations of control (white bars) and coral (grey bars) mesocosms. APF, ANF: autotrophic pico- and nanoflagellates respectively. Pico- and nanoplankton were divided into 3 different size fractions $(<2,<5$ and $<10 \mu \mathrm{m}$ fractions) 


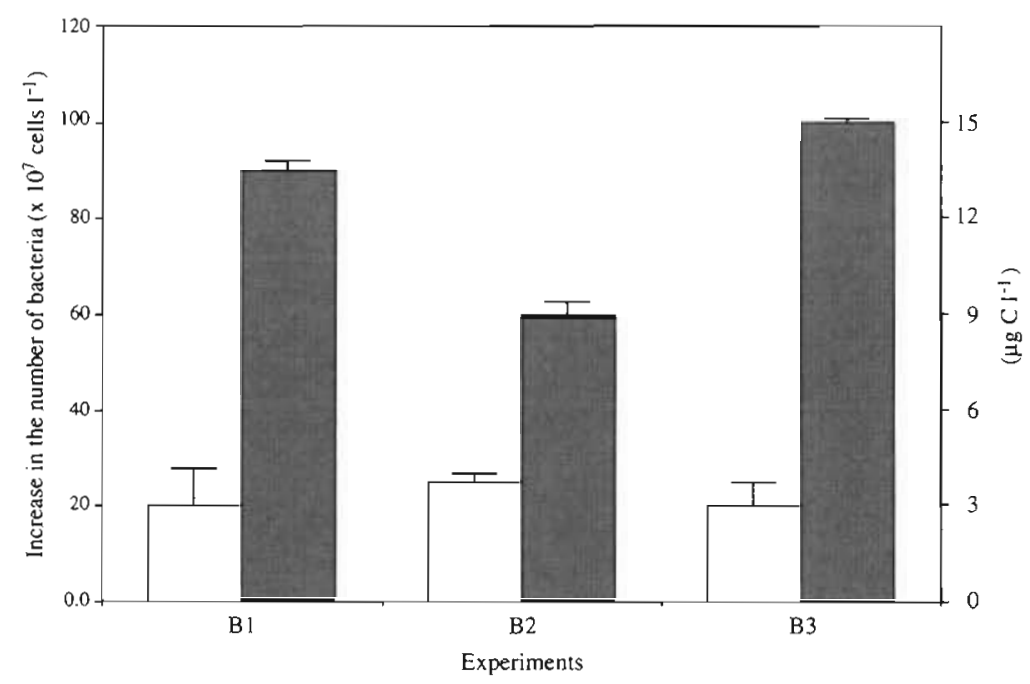

Fig. 4. Expts B1, B2 and B3. Increases in bacterial concentrations (cell $\mathrm{ml}^{-1}$ ) and carbon biomass $\left(\mu \mathrm{g} \mathrm{C}^{-1}\right.$ ) during a $10 \mathrm{~h}$ incubation in the control (white bars) and the coral (grey bars) mesocosms

Takahashi 1983, Berman et al. 1984), and the same major microbial lineages are widespread (Sorokin 1981, Waterbury et al. 1986, Cole et al. 1988, Mullin et al. 1995). Moreover, gross growth efficiencies of bacterioplankton growing on natural DOC sources vary from 2 to $45 \%$ in marine ecosystems ranging from tropical to polar areas (Carlson \& Ducklow 1996).

Grazing of pico- and nanoplankton by higher trophic levels can be roughly estimated in Expt A by calculating the difference in biomass increase between 2 size fractions (Figs. $2 \& 3$ ). Our results indicate that at least 25 to $30 \%$ of the daily microbial production was consumed by higher trophic levels (mainly heterotrophic nanoflagellates and ciliates). This active protozoan grazing of rapidly growing pico- and nanoplankton led to an efficient transfer of energy from lower to higher trophic levels. This seems to be the case for most

varying from 2 to $45 \%$ (Carlson \& Ducklow 1996). This corresponds to $0.3-10 \%$ of the maximum DOC concentrations in these mesocosms. Thus, only small amounts of nutrients were needed to sustain high microbial production rates. Indeed, other authors (Carlson \& Ducklow 1996, Zweifel et al. 1996) have calculated that freeliving bacterioplankton consume 0.04 to $1 \mu \mathrm{mol} \mathrm{C} \mathrm{^{-1 }}$ $\mathrm{h}^{-1}$ DOC. Moreover, DOC excreted by corals is likely a by-product of photosynthesis, and is thus more labile than seawater DOC.

Our findings indicate that the growth of both autoand heterotrophic microbes was enhanced by coral exudates. Bacteria experienced the highest increase in biomass (at least 6 -fold), as would be expected from the addition of organic nutrients. Autotrophic microbial biomass was enhanced by 3 - to 5 -fold in coral mesocosms relative to control mesocosms. Although autotrophic cells rely principally on dissolved inorganic nutrients, it has been demonstrated that they can also take up DOM such as amino acids (Flynn \& Butler 1986, Palenik \& Morel 1990). Autotrophic microbial biomass enhancement could have also been caused by an increase in inorganic nutrients, excreted by corals (Szmant et al. 1990, Schlichter \& Liebezeit 1991) or recycled by bacteria. A rapid uptake of these nutrients by the phytoplankton could explain the lack of variation in inorganic nutrient concentrations during the incubations.

Planktonic populations, taken from Mediterranean surface waters, could be slightly different from coral reef microbes. However, both ecosystems are oligotrophic and have comparable microbial concentrations (Sherr et al. 1989, Ayukai 1991). Small phytoplankton dominate the autotrophic biomass (Bienfang \& coral reefs characterized by fast and efficient nutrient recycling and low inputs of new nutrients (Crossland \& Barnes 1983).

In conclusion, planktonic bacteria seem to take up small amounts of coral exudates. However, these amounts are sufficient to enhance bacterial production by 6 -fold and autotrophic production by 3 - to 5 -fold. Further studies should be directed to determine the lability of DOC compounds excreted by corals.

Acknowledgements. Thanks are due to D. Allemand for his assistance, J. Dolan for reviewing this manuscript, and M. D. Pizay for inorganic nutrient analysis. This work was funded by the 'Centre Scientifique de Monaco', by the Council of Europe, and by the European Commission through MAS3CT95-0016 (MEDEA)

\section{LITERATURE CITED}

Ayukai T (1991) Standing stock of microzooplankton on coral reefs: a preliminary study. J Plankton Res 13:895-899

Berman T, Azov Y, Townsend D (1984) Understanding oligotrophic oceans: can eastern Mediterranean be a useful model? In: Holm-Hansen O, Bolis L, Gilles R (eds) Marine phytoplankton and productivity: lecture notes on coastal and estuarine studies, Vol 8. Springer-Verlag, Berlin, p $101-112$

Bienfang PK, Takahashi M (1983) Ultraplankton growth rates in a subtropical ecosystem. Mar Biol 76:203-211

Capone DG, Dunham SE, Horrigan SG, Duguay LE (1992) Microbial nitrogen transformations in unconsolidated coral reef sediments. Mar Ecol Prog Ser 80:75-88

Carlson CA, Ducklow HW (1996) Growth of bacterioplankton and consumption of dissolved organic carbon in the Sargasso Sea. Aquat Microb Ecol 10:69-85

Caron DA (1983) Technique for enumeration of heterotrophic 
and phototrophic nanoplankton, using epifluorescence microscopy and comparison with other procedures. Appl Environ Microbiol 42(2):491-498

Caron DA, Dam HG, Kremer P, Lessard EJ, Madin LP, Malone TC, Napp QJM, Peele ER, Roman MR, Youngbluth MJ (1995) The contribution of microorganisms to particulate carbon and nitrogen in surface waters of the Sargasso Sea near Bermuda. Deep-Sea Res 42:943-972

Charpy L, Blanchot J, Lo L (1992) Cyanobacteria Synechococccus spp. contribution to primary production in a closed atoll lagoon (Takapoto, Tuamotu, French Polynesia). CR Acad Sci Paris 314:395-401

Charpy-Roubaud C, Charpy L, Sarazin G (1996) Diffusional nutrient fluxes at the sediment-water interface and organic matter mineralization in an atoll lagoon (Tikehau, Tuamotu Archipelago, French Polynesia). Mar Ecol Prog Ser 132:181-190

Coffroth MA (1990) Mucous sheet formation on poritid corals: an evaluation of coral mucus as a nutrient source on reefs Mar Biol 105:39-49

Cole JJ, Findlay S, Pace ML (1988) Bacterial production in fresh and saltwater ecosystems: a cross-system overview. Mar Ecol Prog Ser 43:1-10

Crossland CJ (1987) In situ release of mucus and DOC-lipid from the coral Acropora variabilis and Stylophora pistillata. Coral Reefs 6:35-42

Crossland CJ, Barnes DJ (1983) Dissolved nutrients and organic particulates in water flowing over coral reefs at Lizard Island. Aust J Mar Freshw Res 34:835-844

D'Elia CF, Wiebe WJ (1990) Biogeochemical nutrient cycles in coral reef ecosystems. In: Dubinsky $Z$ (ed) Coral reefs, ecosystems of the world, Vol 25. Elsevier, Amsterdam, p 49-74

Ducklow HW (1990) The biomass, production and fate of bacteria in coral reefs. In Dubinsky $\mathrm{Z}$ (ed) Coral reefs, ecosystems of the world, Vol 25. Elsevier, Amsterdam, p 265-289

Ducklow HW, Mitchell R (1979) Bacterial populations and adaptations in the mucus layers on living corals. Limnol Oceanogr 24:715-725

Ferrier-Pagès C, Gattuso JP (1998) Biomass, production and grazing rates of pico- and nanoplankton in coral reef waters (Miyako Island, Japan). Microb Ecol 35:46-57

Ferrier-Pagès C, Gattuso JP, Cauwet G, Jaubert J, Allemand $D(1998)$ Release of dissolved organic carbon and nitrogen by the zooxanthellate coral Galaxea fascicularis. Mar Ecol Prog Ser 172:265-274

Flynn KJ, Butler I (1986) Nitrogen sources for the growth of microalgae: role of dissolved free amino acids. Mar Ecol Prog Ser 34:281-304

Furnas MJ, Mitchell AW (1986) Phytoplankton dynamics in the Central Great Barrier Reef. 1. Seasonal changes in biomass and community structure and their relation to intensive activity. 2. Primary production. Cont Shelf Res 6: 363-384

Furnas MJ, Mitchell AW, Gilmartin M, Revelante N (1990) Phytoplankton biomass and primary production in semienclosed reef lagoons of the Central Great Barrier Reef, Australia. Coral Reefs 9:1-10

Hatcher BG, Sanmarco PW (1983) The role of detritus in the metabolism and secondary production of coral reef ecosystems. In: Baker JT, Carter RM, Stark KP (eds) Proceedings Inaugural Great Barrier Reef conference. James Cook University, Townsville, p 317-326

Herndl GJ, Velimirov B (1986) Microheterotrophic utilization of mucus released by the Mediterranean coral Cladocora cespitosa. Mar Biol 90:363-369

Leclercq N, Gattuso JP, Jaubert J (1999) Measurements of oxygen metabolism in open-top aquatic mesocosms: appli- cation to coral reef community. Mar Ecol Prog Ser 177: 299-304

Lewis JB (1977) Processes of organic production on coral reefs. Biol Rev 52:305-347

Linley EAS, Koop K (1986) Significance of pelagic bacteria as a trophic resource in a coral reef lagoon, One Tree Island, Great Barrier Reef. Mar Biol 92:457-464

Means JC, Sigleo AC (1986) Contribution of coral reef mucus to the colloidal pool in the vicinity of Discovery Bay, Jamaica. W I Bull Mar Sci 39:110-118

Moriarty DJW (1979) Biomass of suspended bacteria over coral reefs. Mar Biol 53:193-200

Moriarty DJW, Pollard PC, Hunt WG (1985) Temporal and spatial variation in bacterial production in the water column over a coral reef. Mar Biol 85:285-292

Mullin TD, Britschgi TB, Krest RL, Giovannoni SJ (1995) Genetic comparisons reveal the same unknown bacterial lineages in Atlantic and Pacific bacterioplankton communities. Limnol Oceanogr 40(1):148-158

Palenik B, Morel FMM (1990) Amino acid utilization by marine phytoplankton: a novel mechanism. Limnol Oceanogr 35:260-269

Paul JH, DeFlaun F, Jeffrey WH (1986) Elevated levels of microbial activity in the coral surface microlayer. Mar Ecol Prog Ser 33:29-40

Pelegrí SP, Dolan J, Rassoulzadegan F (1999) Use of high temperature catalytic oxidation (HTCO) to measure carbon content of microorganisms. Aquat Microb Ecol 16:273-280

Porter KG, Feig YS (1980) The use of DAPI for identifying and counting aquatic microflora. Limnol Oceanogr 25:943-948

Schiller C, Herndl GJ (1989) Evidence of enhanced microbial activity in the interstitial space of branched corals: possible implications for coral metabolism. Coral Reefs 7: $179-184$

Schlichter D, Liebezeit G (1991) The natural release of amino acids from the symbiotic coral Heteroxenia fuscescens (Ehrb.) as a function of photosynthesis. J Exp Mar Biol Ecol 150:83-90

Sherr EB, Rassoulzadegan F, Sherr BF (1989) Bacterivory by pelagic choreotrichous ciliates in coastal waters of the NW Mediterranean Sea. Mar Ecol Prog Ser 55:235-240

Smith SV, Kimmerer WJ, Laws EA, Brock RE, Walsh TW (1981) Kaneohe Bay sewage diversion experiment. Perspectives on ecosystem responses to nutritional perturbation. Pac Sci 35:279-396

Sorokin YI (1981) Microheterotrophic organisms in marine ecosystems. In: Longhurst AT (ed) Analysis of marine ecosystems. Academic Press, New York, p 293-382

Sorokin YI (1993) Coral reef ecology. Ecol Stud 102

Sorokin YI (1994) Role of plankton in the turnover of organic matter on the Great Barrier Reef, Australia. Hydrobiologia 308:35-44

Strickland JDH, Parsons TR (1972) A practical handbook of seawater analysis, 2nd edn. Bull Fish Res Bd Can 167

Szmant AM, Ferrer LM, FitzGerald LM (1990) Nitrogen excretion and O:N ratios in reef corals: evidence for conservation of nitrogen. Mar Biol 104:119-127

Waterbury JB, Watson SW, Valois FW, Franks DG (1986) Biological and ecological characterization of the marine unicellular Cyanobacterium Synechococcus. Can Bull Fish Aquat Sci 214:71-120

Williams PJleB (1981) Incorporation of microheterotrophic processes into the classical paradigm of the planktonic food web. Kiel Meeresforsch 5:1-28

Zweifel UL, Blackburn N, Hagström $\AA$ (1996) Cycling of marine dissolved organic matter. I. An experimental system. Aquat Microb Ecol 11:65-77 